\title{
The processes of urban sprawl in the environment of mid-size cities during the period of expansive urbanism. Territorial impact in an interior area (Castilla-La Mancha, Spain)
}

\section{Francisco Cebrián Abellán, Irene Sánchez Ondoño}

Departamento de Geografía y Ordenación del Territorio. Universidad de Castilla-La Mancha.

Albacete, Spain

E-mail: juanmiguelmunoz.corbalan@ub.edu

\begin{abstract}
The processes of urban sprawl have increased since the end of the century. They have occurred in a context of economic prosperity, in which part of the capital surplus has been directed towards the construction industry, and especially towards the dwellings. The dynamic has been reproduced in the different scales of the urban hierarchy. Much of the new urban developments and constructions have been directed to the peripheral areas. Urban sprawl has increased in the environment of big cities, but also around medium-sized cities. This reality is manifested differently, depending on the case, but it has also left some general processes. In this essay attention has been centered on the changes in the housing in the peripheries of the Spanish medium-sized cities. The changes between 1991 and 2016 in a radius of 30 around the cities selected have been analyzed in order to identify the scope of urban sprawl, the temporary differences in the process and the most common collected ones. As an object of analysis seven inner and remote cities of Castilla- La Mancha have been used. We can observe a priori differentiating processes, and others that respond to logics associated to the influence of the polynuclear metropolitan area of Madrid.
\end{abstract}

Keywords: Mid-size city, urban sprawl, expansive urbanism, inner cities, Castilla-La Mancha

\section{The trivialization of urban sprawl}

The transformations produced in recent decades in urban spaces bring associated changes in functions, structures and landscapes. This has meant a certain redefinition of the traditional model of city, which includes, among other things, the transition from compact morphologies to a growing role of diffusion and urban sprawl. Urban Sprawl began to be patent in United States after the Second World War (Garreau, 1994), evolving towards the deterritorialization and reterritorialization of the city in the peripheries (Soja, 2008, 222). Since then it has been spreading to other sociocultural contexts of the developed areas, in which peri-urban landscapes have been becoming routine and banal, reproduced in most cases under the dispersed city of low building density patterns. Its incidence is such that it is identified as one of the most important problems arising for the 21 st century (Arellano and Roca, 2010). The process affects the different scales of the urban hierarchy. It is especially striking and manifest in large metropolitan areas, but it is also becoming more common in the mid-sized environments, where their effects are less intense and their territorial scope is smaller (Richardson, 2004; Hoggart, 2005; Phepls et al, 2006; EEA, 2006; DeMatteis, 2015).

The change of city model possibly responds to diverse reasons, although they act jointly and with uneven effect. Sometimes transformation 
engines are of global scope, and others are due to local situations. Some have a high processing capacity, while others accompany and increase the role of the first ones. Among the structural ones, we highlight those played by the information society and the spread of ICTs.

It is what has been termed as network society (Castells, 2006), that has favored new types of relations, substituting proximity by connectivity, distance by time... These changes have opened a new stage to the automobile and remote connection scope beyond the limits of the traditional city. The growing interest of the capital on investing and immobilize financial surpluses in urban spaces is global, thus supporting the construction of new buildings, in many cases under forms of dispersed city. The strategies employed have been diverse: on the one hand, the granting of credits to the public sector (for new urban developments and creationand/orimprovement of infrastructures); on the other hand, loans to the private sector (developers -who get big capital gains on the conversion of rural land into urban - and final homebuyers through the mortgage market) (Harvey, 1985, 2005, 2013). In most of cases, they have had a clear speculative function, in addition to the actual production.

The role of the Governments in recent decades has been strategic at different levels, in a generalized context of neoliberal policies. The Administration has progressively left aside the regulatory task of land markets, reducing their function, and limiting it to the intervention in urban, regional and spatial planning (Harvey, 2013, 52). On the other hand, we can also see this in the support to homeownership through tax reductions or exemptions from taxes. It has been therefore a crucial actor in the process of construction and reconstruction of traditional cities, but also of peripheral housing estates (Harvey, 2013, 77). Added to all this, the consideration of the real estate sector as an engine for employment and income generation, in a context of expansive economy and surplus of capital in the public and private sectors.

To these general processes, others specific to each society are added. The Spanish construction sector has been immersed in a special growth, in the period between 1998 and
2008. These years of unprecedented dynamics have been qualified under explanatory and suggestive names: "prodigious decade of urbanism" (Burriel, 2014), "urban tsunami" (Gaja, 2008), "pathological drift" (Roch, 2015).The urbanized area and housing, public infrastructure, industrial spaces, large social and leisure equipment, and the land have grown very fast (and nearly uncontrolled)... The reasons for the strong expansion of the real estate sector are linked to: rise in incomes; fall in interest rates; favorable policies to obtain credits to buy a house (rather than rental) (Romero, 2010, 23; Gaja, 2008); massive arrival of labour immigrants; increase in the demand of second homes in the traditional sun and beach destinations (both by Spaniards and foreigners); incorporation of financial institutions to the housing sector (Herce, 2013, 349; Lois et al., 2016, 14); proliferation of private investors, many of them with speculative zeal; changes of consumer preferences; more permissive land legislation, which turned practically everything on building land, and which was accompanied by the figure of the urbanization agent (Gaja, 2008); influence of promoters enterprises and construction on public administrations, especially small municipalities, with many examples of urban corruption (Lois, and Piñeira, 2016, 243)... The result has been a massive production of urban space, a false material expansion, that does not correspond with population growth or the construction of any new cumulative order (Roch, 2015, 59).

The processes previously targeted have had obvious territorial and urban effects in most of the peripheries of the Spanish cities. There has been a certain breakdown of the traditional urban fabric for the benefit of new ways that favor the dispersion and territorial (and social) segregation. The essential condition for the creation of these new forms of town outside the city has been the improvement of connectivity (ICT -dependent on the private sector- and communication -roads-, responsibility of the management infrastructure). They have been especially strong in the surroundings of the large metropolitan areas. It has also become apparent in urban and peri-urban coastal areas of strong implementation of residential sun 
and beach tourism. Scientific literature has given these issues much attention. The midsized interior places have been given much less treatment, and they are here discussed from the perspective of the evolution of housing.

The urban sprawl in the middle of the Spanish peninsular interior cities: Castilla La Mancha.

\section{Methodological proposal}

This work deals with a complex aspect, urban sprawl, which does not appear clearly defined (Cebrián, 2013), in the context of intermediate cities, on which there is not an agreement. This category of the urban hierarchy has been considered within the range between fifty and three hundred thousand inhabitants (Mega, 2000). As case study we have chosen a group of inner cities, in which the effects of residential tourism have hardly been present. They have been selected because the processes of urban sprawl are explained for reasons associated with their respective internal dynamics, but they are also understood on occasions by the influence of a great city nearby, which generates sprawl and urban and functional overflow towards them. In this case, the analysis is applied in Albacete, Ciudad Real, Cuenca, Guadalajara, Toledo, Talavera de la Reina and Puertollano. All of them have a population between fifty and two hundred thousand inhabitants, and belong to the autonomous community of Castilla - $\mathrm{La}$ Mancha (Spain).

Some general features help to explain and understand the structure of the urban network of this region. The distribution and size of the cities in the territory has not left a urban nucleus important enough to organize the other cities and, consequently, the regional territory. For this reason, it can be understood as a headless region, without any great catalyst center, since bigger cities are peripheral, and preside over urban systems of provincial level in most of cases, while the interior towns are smaller and have regional spheres of influence (Cebrián, 2007, 179). It is not the object of this work to consider the functional orientation of each of them. We should bear in mind that there is a large city located in the center of the country, which dominates part of the national urban system, that penetrates and organizes functionally much of the regional territory. The polynuclear metropolitan area of Madrid has a noticeable influence on Guadalajara and Toledo, following the route of the main roads that connect these two cities with the national capital (Burriel, 2014).

The objective of the essay is focused on two aspects: on the one hand, the real scope of the processes of urban sprawl in these seven cities; on the other hand, identify the incidence that the building typologies of low density in the process (single-family homes) have had. We have resorted to an analytical methodology, using the cadastre (General direction of Cadastre, Ministry of Finance and Public Service, Government of Spain), which some authors consider to have high reliability and accuracy (Mora-Garcia et al., 2015; Santos et al., 2014), and specifically open access files ".Cat". The territorial scope of analysis is a radius of 30 kilometers around each town. From the information available in the virtual headquarters of the cadastre ( $<$ https://www. sedecatastro.gob.es $>$, accessed 28 February 2017), a work of extraction and conversion of records has been made, selecting some variables related to housing. The data were presented in an aggregate and very brief way. The considered temporary cycle is between 1991 and 2016, reorganized into three periods, in order to have an overview of the years prior to the expansive city planning (19911998), of what happened in the years of major construction in Spain (1999-2008), and what has happened since the crisis (2009-2016).

The variables were employed to identify, at the level of municipality, the temporal and territorial evolution of the number of dwellings by category. For this purpose the following record types have been used: on the one hand, and in order to meet changes in the total number of homes, the type of register 15 (real estate) has been employed, within the category of urban class (UR) that are coded with the $\mathrm{V}$ use (residential); on the other hand, and in order to meet changes in the building typology, we have resorted to the type of register 14 (Construction), using the 
constructive typologies: 1.1 Urban collective housing (including the categories 1.1.1: collective housing of urban, open building, and 1.1.2.: collective housing of urban character, building in a closed block of buildings) and 1.2. urban single-family homes (which collects the typologies: 1.2.1.: single-family homes of urban and isolated or semi-detached buildings, and 1.2.2.: single-family homes of urban character, built in line or in closed block of buildings). To obtain the total values of housing by building typology at municipality level, the category 1.3.1. (exclusive use of housing and construction) is also included.

The resulting data have been mapped to scale of municipality, in order to identify changes in relation to the year of reference (1990). Another part of data added for different considered periods has been presented in tables, including data grouped in selected time periods and large territorial units (municipality where the central city is located, and the set of municipalities that make up the respective urban crowns). We must bear in mind that the scale of analysis (municipality) leaves disparate realities, by the substantial demographic and territorial differences that exist in them, and because the settlement models are not homogeneous. You must also consider data grouped into time series, comprising approximately a decade, so the specific situations of each year are masked in what happened during the entire period.

The processes of urban sprawl in the peripheries of the mid-sized cities of Castilla - La Mancha. Evolution and distribution of the overall real estate.

Some general ideas that contribute to present what happened at the territorial level and in the temporary field can be extracted from the analysis of the data. On the one hand, it highlights the fact that many more homes in the crowns have been built (more than two hundred thirty thousand) than in central cities (one hundred thirty-four thousand). On the other hand, the remarkable difference in the models followed by seven cities considered should be emphasized.

In some cases the growth of housing (real estate) has been primarily focused in the municipality in which the central city is located (in comparison with what happened in the municipalities located in the crown): especially in the cases of Albacete and Cuenca. A prominent role of peripheries (Puertollano, Ciudad Real and Talavera de la Reina) appears on the other cases. However, it is striking that in some cases urban crowns are clearly the most dynamic (situation that is perceived so clearly in Toledo and Guadalajara, where actual housing growth has been concentrated outside the two capitals - in fact, the growth of housing has been five times higher in the crown than in the municipality that is home to the central city).

From the temporal point of view, there are several interesting issues. It is patent the effect that a period of expansive urbanism has had in main cities of Castilla - La Mancha: between 1999 and 2008 is when more housing there has been (almost two hundred five thousand). But it is also this period in which more intensity and relevance the dynamics of urban areas there have been: in those years more than one hundred thirty-six thousand homes in the respective crowns have been built $(66 \%$ of new homes have been built in the peripheral municipalities). It is not a new phenomenon, since this situation was already clear in the previous period (1991-1998), in which the total number of collected homes was about half than in the expansive urbanism, of which 56\% was already built in urban peripheries, and the cases of Toledo and Guadalajara were already heavily influenced by forms of urban sprawl in their respective crowns (Table 1).

Considering the role played by the building typology of low density, some singularities can also be targeted. On the one hand, the strong establishment that urban single-family homes have had (1.2) in the urban crowns along two first periods considered. This has been the dominant construction typology (twice that of the block housing). On the other hand, it is striking that seven crowns have had the main form of urban development on the constructive typologies of low density until 2008. From that moment the process has been reversed, and the collective housing appears as the dominant construction typology again (Table 2).

At the municipal level we can see the acceleration produced until 2008 in the maps of the first two periods considered (the most 
dynamic in terms of homes built (Maps 1 to 4), especially striking in the municipalities close to Guadalajara and Toledo. The process maintains a special intensity towards Madrid, where there is a growing attraction and functional integration. In the other cities of the region, the phenomenon is less intense, although nearby municipalities which have been especially benefited usually appear (Maps 1 and 2).

\section{Conclusion}

The effects of the expansive city planning, understood through the evolution of the housing typologies at municipality level, have been manifested in all the analyzed cases. It has been patchy in intensity and scope, with the uniqueness that its dynamics has been especially striking in the crowns of Guadalajara and Toledo. As a general rule its intensity can be outlined in the municipalities close to cities and close to high capacity roads. But above all in the area of immediate influence of Madrid. The impairment of the phenomenon is also evident as the distance grows, suggesting that the threshold of $30 \mathrm{Km}$ exceeds the area of real influence. It is catching the elevated role assumed by single-family homes, which have taken over the landscape and have been the main exponent of the increase in housing until 2008. On the other hand, it seems that the crisis has served as a brake on the dynamics, and also a change in the trend in constructive modalities for the block of buildings.

\begin{tabular}{|c|c|c|c|c|c|c|c|c|}
\hline & \multicolumn{2}{|c|}{ 1991-1998 } & \multicolumn{2}{|c|}{ 1999-2008 } & \multicolumn{2}{|c|}{ 2009-2016 } & \multicolumn{2}{|c|}{ TOTAL (1991-2016) } \\
\hline & $\begin{array}{c}\text { Central } \\
\text { City }\end{array}$ & $\begin{array}{l}\text { Urban } \\
\text { crown }\end{array}$ & $\begin{array}{c}\text { Central } \\
\text { city }\end{array}$ & $\begin{array}{l}\text { urban } \\
\text { crown }\end{array}$ & $\begin{array}{l}\text { Central } \\
\text { city }\end{array}$ & $\begin{array}{l}\text { Uurban } \\
\text { crown }\end{array}$ & $\begin{array}{c}\text { Central } \\
\text { city }\end{array}$ & $\begin{array}{l}\text { urban } \\
\text { crown }\end{array}$ \\
\hline Albacete & 14749 & 1384 & 17589 & 3058 & 5697 & 1058 & 38035 & 5500 \\
\hline Cuenca & 3594 & 1196 & 7838 & 2049 & 1342 & 893 & 12774 & 4138 \\
\hline Ciudad-Real & 6407 & 6776 & 11349 & 13504 & 2375 & 3322 & 20131 & 23602 \\
\hline Guadalajara & 6182 & 24957 & 10147 & 57331 & 2564 & 12963 & 18893 & 95251 \\
\hline Puertollano. & 3092 & 2250 & 4658 & 2885 & 1445 & 848 & 9195 & 5983 \\
\hline Talavera de la Reina & 6254 & 4020 & 7829 & 8324 & 1389 & 1947 & 15472 & 14291 \\
\hline Toledo & 7075 & 20943 & 9043 & 48857 & 3416 & 12260 & 19534 & 82060 \\
\hline TOTAL & 47353 & 61526 & 68453 & 136008 & 18228 & 33291 & 134034 & 230825 \\
\hline $\begin{array}{r}\text { TOTAL CITY + } \\
\text { CROWN }\end{array}$ & & 108879 & & 204461 & & 51519 & & 364859 \\
\hline
\end{tabular}

Source: Cadastre, Own research, 2017.

Table 1. Real estate evolution.

\begin{tabular}{|c|c|c|c|c|c|c|c|c|c|c|c|c|c|c|c|c|}
\hline & \multicolumn{4}{|c|}{ 1991-1998 } & \multicolumn{4}{|c|}{ 1999-2008 } & \multicolumn{4}{|c|}{ 2009-2016 } & \multicolumn{3}{|c|}{ TOTAL (1991-2016) } & \\
\hline & \multicolumn{2}{|c|}{ Central City } & \multicolumn{2}{|c|}{ Urban crown } & \multicolumn{2}{|c|}{ Central city } & \multicolumn{2}{|c|}{ Urban crown } & \multicolumn{2}{|c|}{ Central city } & \multicolumn{2}{|c|}{ Urban crown } & \multicolumn{2}{|c|}{ Central city } & \multicolumn{2}{|c|}{ Urban crown } \\
\hline & 1.1. & 1.2. & 1.1. & 1.2. & 1.1. & 1.2. & 1.1. & 1.2. & 1.1. & 1.2. & 1.1. & 1.2. & 1.1. & 1.2. & 1.1. & 1.2. \\
\hline Albacete & 13133 & 1577 & 362 & 1014 & 15446 & 2123 & 1104 & 1946 & 4786 & 910 & 537 & 519 & 33365 & 4610 & 2003 & 3479 \\
\hline Cuenca & 3212 & 380 & 56 & 1454 & 6710 & 1126 & 336 & 1614 & 1237 & 105 & 347 & 479 & 11159 & 1611 & 739 & 3547 \\
\hline Ciudad-Real & 4896 & 1511 & 1936 & 4826 & 9873 & 1476 & 4811 & 8673 & 2218 & 154 & 1595 & 1724 & 16987 & 3141 & 8342 & 15223 \\
\hline Guadalajara & 4662 & 1517 & 10268 & 14891 & 7915 & 2208 & 24504 & 36710 & 5128 & 263 & 8918 & 4436 & 17705 & 3988 & 43690 & 56037 \\
\hline Puertollano & 2677 & 375 & 401 & 1840 & 3791 & 853 & 478 & 2389 & 1198 & 246 & 230 & 615 & 7666 & 1474 & 1109 & 4844 \\
\hline $\begin{array}{l}\text { Talavera de } \\
\text { la Reina }\end{array}$ & 5440 & 811 & 147 & 4367 & 6733 & 1094 & 691 & 7923 & 1080 & 308 & 318 & 1798 & 13253 & 2213 & 1156 & 14088 \\
\hline Toledo & 5612 & 1462 & 2316 & 11522 & 5707 & 3335 & 13522 & 25598 & 3069 & 347 & 4416 & 4417 & 14388 & 5144 & 20254 & 41537 \\
\hline TOTAL & 39632 & 7633 & 15486 & 39914 & 56175 & 12215 & 45446 & 84853 & 18716 & 2333 & 16361 & 13988 & 114523 & 22181 & 77293 & 138755 \\
\hline $\begin{array}{l}\text { TOTAL } \\
1.1 .+1.2 .\end{array}$ & & 47265 & & 55400 & & 68390 & & 130229 & & 21049 & & 30349 & & 136704 & & 216048 \\
\hline
\end{tabular}

Table 2. Real estate evolution by typologies (1.1. In blocks; 1.2. Single family). 


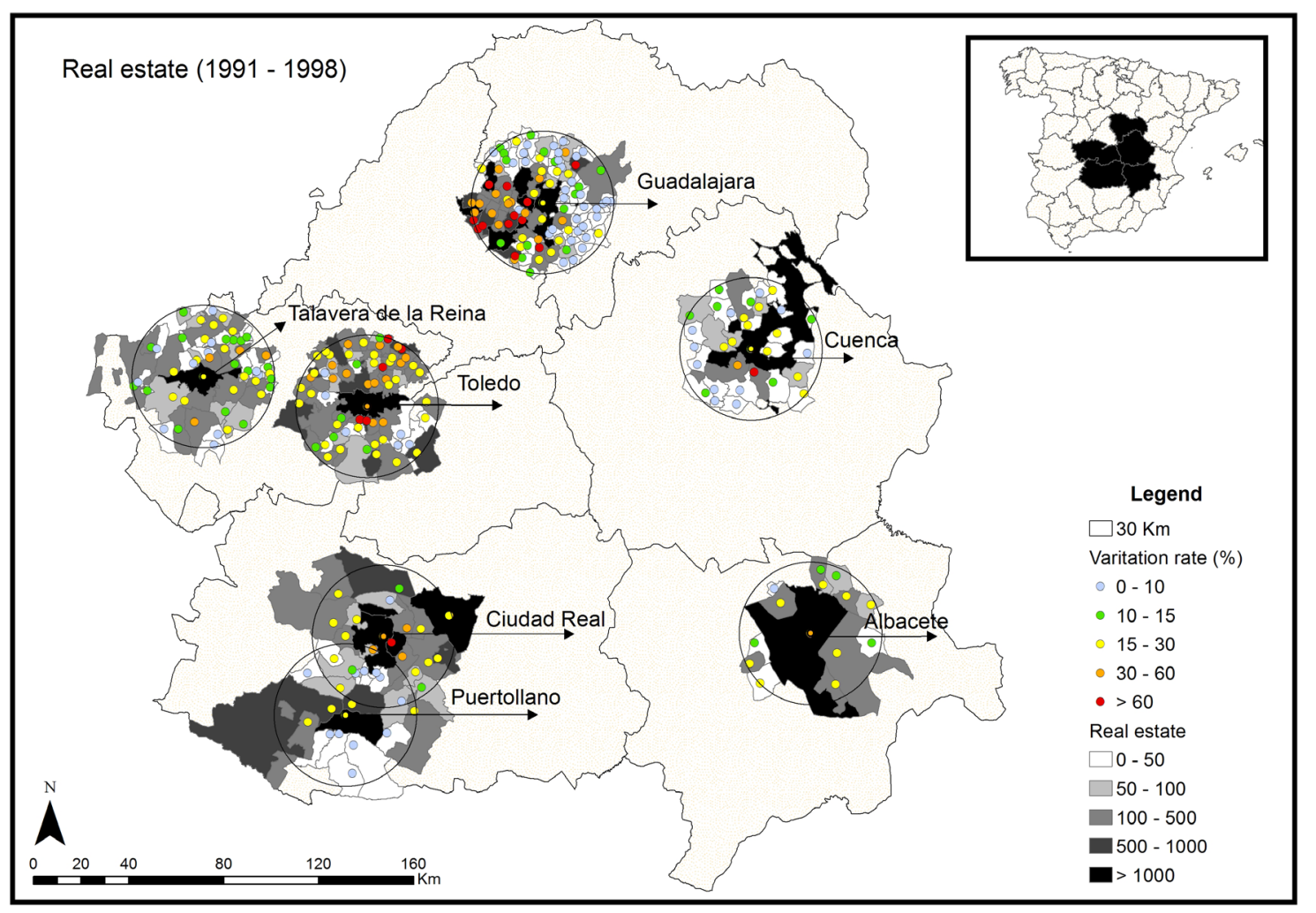

Figure 1. Map 1. Real estate 1991 - 1998.

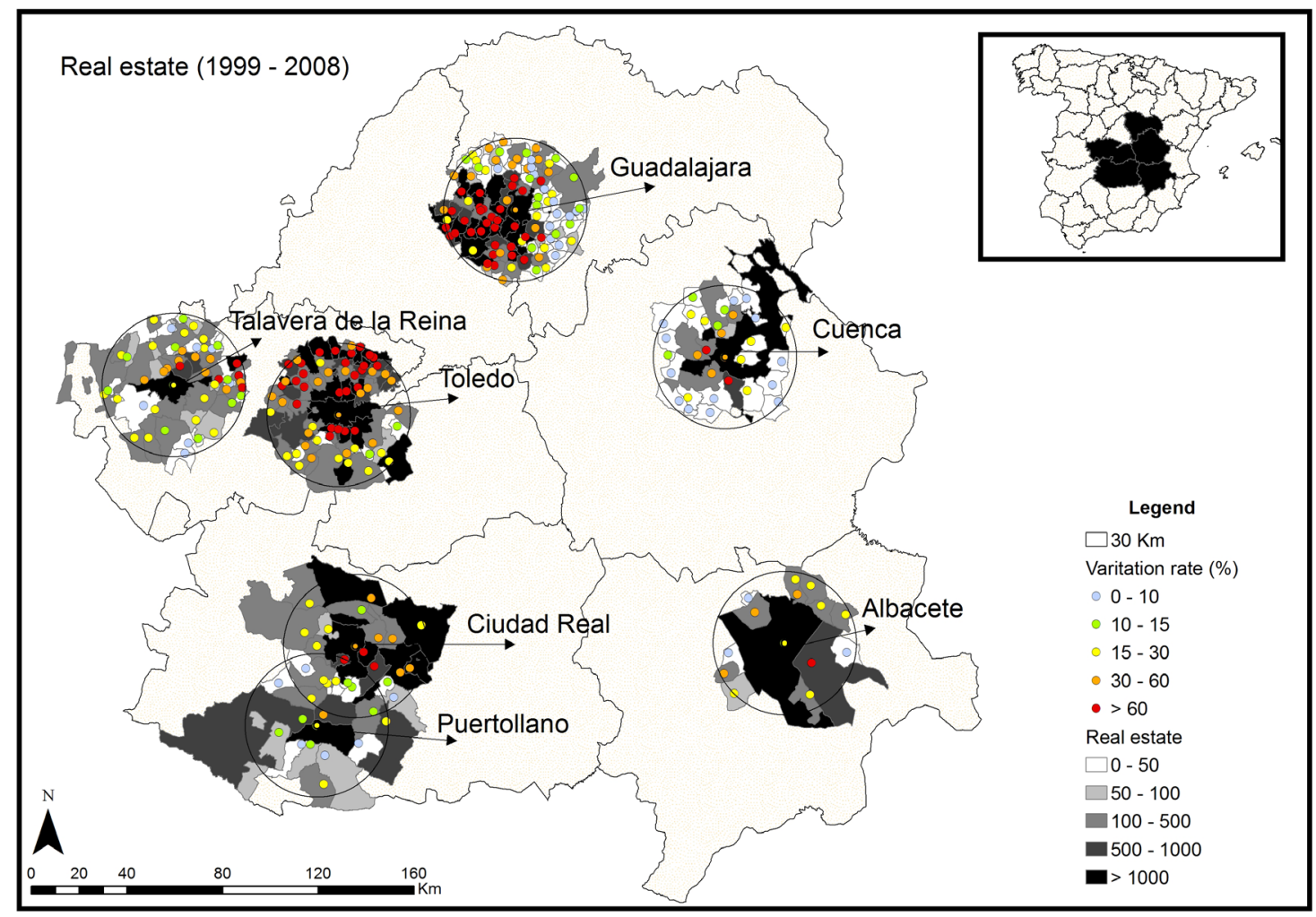

Figure 3. Map 2. Real estate 1999 - 2008. 


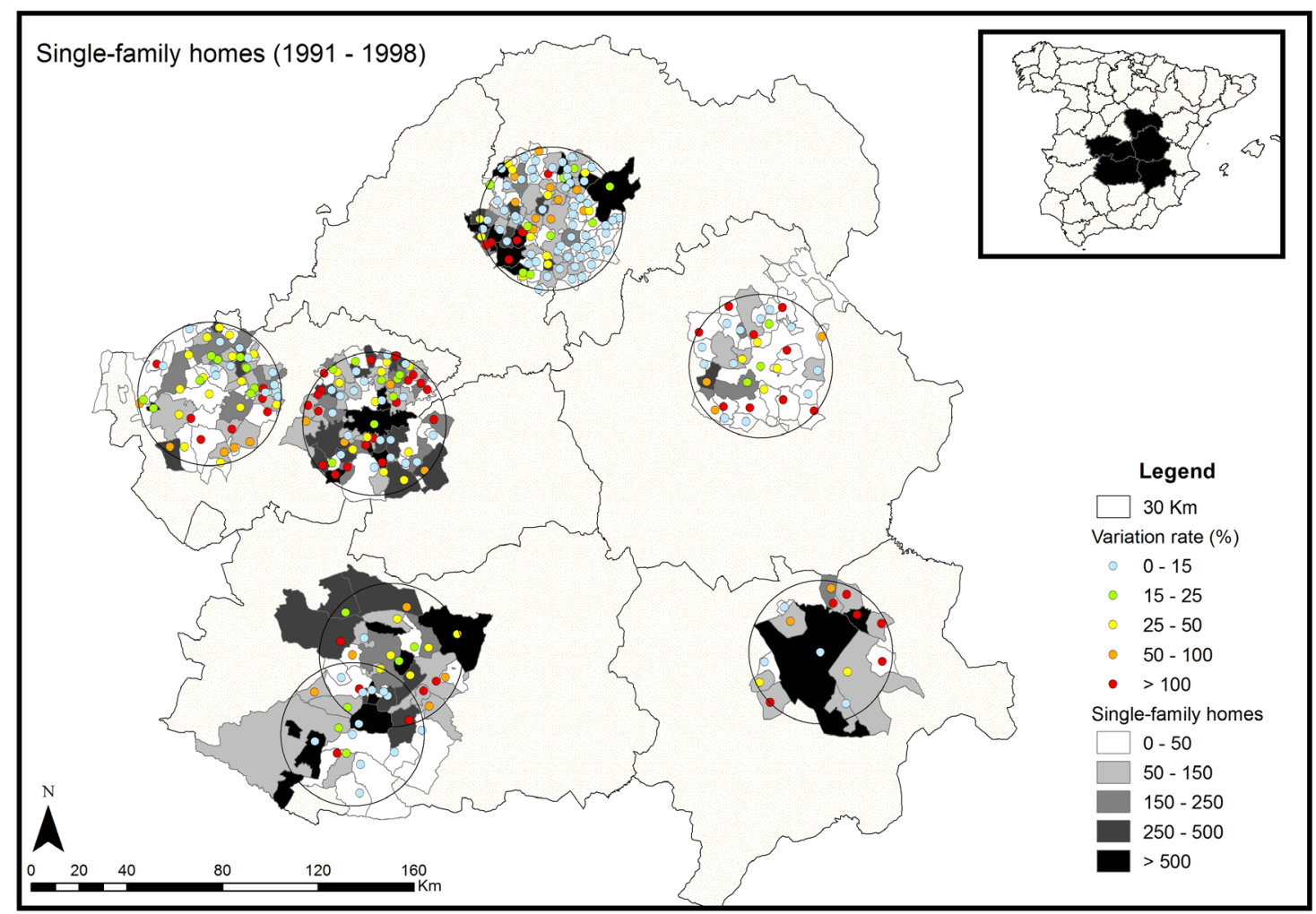

Figure 3. Map 3. Single-family homes 1991 - 1998.

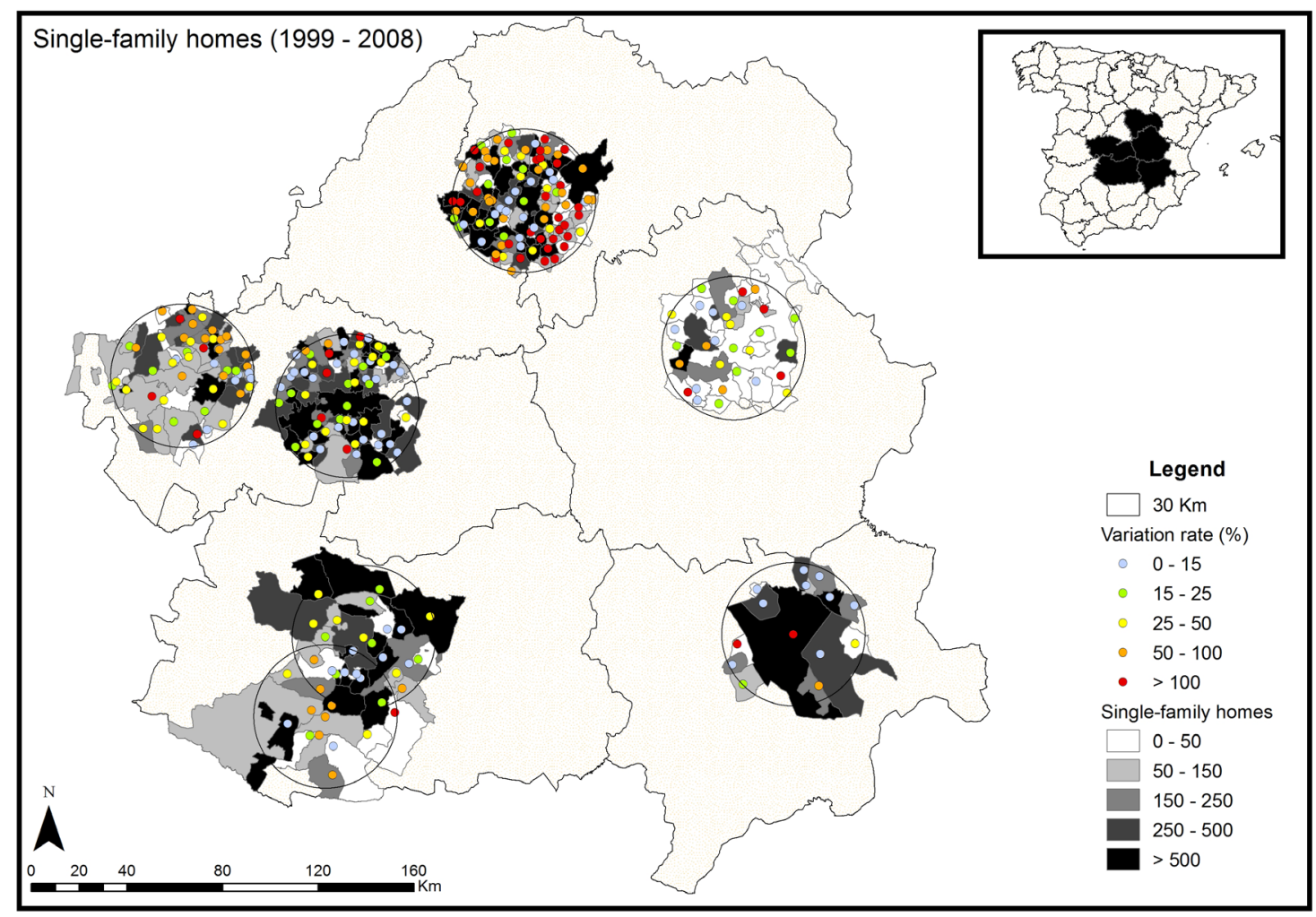

Figure 4. Map 4. Single-family homes $1999-2008$. 
In this case the concrete location of the new constructions has not been analyzed, although it is possible to think that they have sprung up in urban edges of rural centres and next to the central cities. All these reflections, however require to delve into the subject, since as noted at the beginning of this work, the dynamics have been the result of a combination of various factors, which have resulted in some urban morphologies and some constructive typologies that deviate from those that have traditionally characterized these cities, where urban sprawl has had a marginal presence until the beginning of the decade of the nineties of the last century.

\section{Notes}

1. This essay is part of the research project called "Dynamics of urbanization and urban planning policies in mid-sized inner cities. From expansion and dispersal to reformulation, towards a more urban planning? (CSO201563970-R). Financed by Ministry of Economy and Competitiveness and FEDER, Goverment of Spain.

\section{References}

Arellano, B. and Roca, J. (2010) 'El urban Sparwl ¿un fenómeno de alcance plantario? Los ejemplos de España y México', Arquitectura, Ciudad y Entono 12, 115-147.

Burriel, E. (2014) 'El estallido de la burbuja inmobiliaria y sus efectos en el territorio', in Albertos, J. M. et alt. Geografía de la crisis económica en España (Universidad de Valencia, Valencia) 101-140.

Castells, M. (2006) Sociedad red (Alianza, Madrid).

Cebrián, F. (2007) 'La red urbana', in Pillet, F. (ed.) Geografía de Castilla-La Mancha (Almud, Ciudad Real).

Cebrián, F. and Panadero, M. (2013) Ciudades medias. Formas de expansión urbana (Biblioteca Nueva, Madrid).

Dematteis, G. (2015) 'Contraurbanizaçao, periurbanizaçao, cidade dispersa e rede de cidade na Italia', Cidades 21, v. 12.
Gaja, F. (2008) 'El "tsunami urbanizador" en el litoral mediterráneo. El ciclo de hiperproducción inmobiliaria 1996-2006', $\mathrm{X}$ Coloquio Internacional de Geocrítica, University of Barcelona.

Garreau, J. (1994) 'Edge cities', American Demographics February 1994.

Harvey, D. (2005) A brief history of neoliberalism (Oxford University Press, New York).

Harvey, D. (2013) Ciudades rebeldes. Del derecho de la ciudad a la revolución urbana (Akal, Madrid).

Herce, M. (2013) El negocio del territorio. Evolución y perspectivas de la ciudad moderna (Alianza, Madrid).

Hoggart, K. (ed.) (2005) The City's Hinterland: Dynamism and divergence in Europe's periurban territories (Ashgate, Aldershot).

Lois, R. C., Piñeira, M. J. and Vives, S. (2016) 'El proceso urbanizador en España (19902014): una interpretación desde la Geografía y la teoría de los circuitos del capital', Scripta Nova 539, v. XX.

Mega, V. (2000) 'The European archipelago of intermediate cities. A research journey', in Bellet, C. and Llop, J. M. (2000) Ciudades intermedias. Urbanización y sostenibilidad (Milenio, Lérida).

Mora-García, R. T. et al. (2015) 'Reutilización de datos catastrales para estudios urbanos', Análisis espacial y representación geográfica: innovación y aplicación, University of Zaragoza, 295-304.

Phelps, N. et al. (2006) Post-suburban europe: planning and politics at the margins of Europe's capital cities (Palgrave MacMillan, Basigstoke).

Richardson, H. W. (ed.) (2004) Urban Sprawl in Western Europe and the United States (Ashgate).

Roch, F. (2015) 'Revolución neoliberal y utopía. Una batalla inaplazable', Ciudades 18, 49-68.

Romero, J. (2010) 'Construcción residencial y gobierno del territorio en España. De la burbuja especulativa a la recesión. Causas y consecuencias', Revista Cuadernos Geográficos 47, 17-46.

Santos, J. M. et al. (2014) 'Análisis de la estructura urbana, mediante bases de datos 
de detalle. Aplicación al estudio del sector 3, barrio residencial de municipio de Getafe', XVI Congreso de Tecnologías de la Información Geográfica, University of Alicante, 663-675.

Soja, E. W. (2008) Postmetrópolis. Estudios críticos sobre las ciudades y las regiones. Traficantes de Sueños (Madrid). 